\title{
Antifouling Activity of Bacterial Symbionts of Seagrasses against Marine Biofilm-Forming Bacteria
}

\author{
Bintang Marhaeni' ${ }^{1,2}$, Ocky Karna Radjasa ${ }^{3,4^{*}}$, Miftahuddin Majid Khoeri ${ }^{3}$, Agus Sabdono $^{4}$, \\ Dietriech G. Bengen ${ }^{1}$, Herawati Sudoyo ${ }^{3}$
}

${ }^{1}$ Graduate School of Marine Sciences, Bogor Agricultural University, Bogor, West Java, Indonesia; ${ }^{2}$ Department of Fisheries and Marine Science, Soedirman University, Purwokerto, Central Java, Indonesia; ${ }^{3}$ Marine Microbiology Unit, Eijkman Institute for Molecular Biology, Jakarta, Indonesia; ${ }^{4}$ Department of Marine Science, Diponegoro University, Semarang, Central Java, Indonesia. Email: ocky_radjasa@undip.ac.id

Received September $6^{\text {th }}$, 2011; revised October $5^{\text {th }}, 2011$; accepted November $3^{\text {rd }}, 2011$.

\begin{abstract}
Marine biofouling has been regarded as a serious problem in the marine environment. The application of TBT and other heavy metal-based antifoulants has created another environmental problem. The present study explored the possible role of baterial symbionts of seagrasses Thalassia hemprichii, and Enhalus acoroides, which were successfully screened for antifouling activity against marine biofilm-forming bacteria isolated from the surrounding colonies of seagrasses. Bacterial symbionts were isolated and tested against biofilm-forming bacteria resulted in 4 bacterial symbionts capable of inhibiting the growth biofilm-forming isolates. Molecular identification based on 16S rRNA gene sequences revealed that the active bacterial symbionts belonged to the members of the genera Bacillus and Virgibacillus. Further tests of the crude extracts of the active bacterial symbionts supported the potential of these symbionts as the alternative source of environmentally friendly marine antifoulants.
\end{abstract}

Keywords: Biofouling, Antifoulant, Bacterial Symbionts, Seagrasses

\section{Introduction}

A regularly observed phenomenon, marine biofouling, is not only a natural process as a result of organism growth on underwater surfaces [1], but is also undesirable due to massive economic losses to marine industries. Primary biofilm, another phenomenon and is part of marine microfouling creates further threat by facilitating the attachment and metamorphosis of fouling organisms [2]. Bacteria as part of the marine microbial population, have been considered as the primary colonizers within biofilm and play a role as dominant components [3]. It is then reasonable to manipulate the role of these bacterial film by disrupting their growth by applying marine antifoulants.

Along with long-term application of tributyl-tin (TBT)based antifouling paints, there has been an increased concerns due to the increased concentrations resulted in environmental hazards to marine marine ecosystems. It was then the reason for EU countries in 1989, followed by International Maritime Organization (IMO) and the
Maritime Environment Protection Committee (MPEC) to restrict the use of TBT [4]. Since then, the development of alternative environmentally friendly antifoulants has been carried out to find alternative replacements.

Sea grasses are one of the most productive coastal ecosystems and a rich source of secondary metabolites with ecologically important roles such as preventing surface fouling [5]. As an effort to explore the potential of marine antifoulants produced by seagrasses [6], it was reported the potential of seagrasses Cymodocea serrulata and Syringodium isoetifolium in inhibiting the growth of marine biofilm-forming bacteria. This finding has confirmed the possible manipulation of biofilm-forming bacteria in reducing the effects of marine biofouling.

The fact that the problem of supply has hampered the development of most secondary metabolites from marine organisms and plants, thus, it is important to highlight the possible role of marine bacteria associated with seagrasses in providing an alternative to the commercial metal-based antifouling coatings. Bacteria-seagrass association that occurs on the seagrass surface then could be 
of great interest to search for potential use as commercial antifoulants.

In this work, we report the potential of marine bacteria associated with seagrasses Thalassia hemprichii, and Enhalus acoroides for controlling the growth marine biofilm-forming bacteria. Antibacterial assays of the bacterial symbionts and their crude extracts confirmed the potential role of these symbionts as the source of environmentally friendly marine antifoulants.

\section{Materials and Methods}

\subsection{Sampling and Isolation of Bacterial Symbionts of Seagrasses}

Colonies of seagrasses Thalassia hemprichii, and Enhalus acoroides were collected from seagrass beds in the Teluk Awur waters, Jepara, Central Java, Indonesia (Figure 1) by hands. Upon collection seagrass colonies were put into sterile plastic bags (Whirl-Pak, Nasco, USA. The colonies were then rinsed with sterile seawater and scraped off with a sterile knife for the isolation of epiphytes. As for isolation of endophytes, the surfaces of seagrass leafs were sterilized with $70 \%$ alcohol, and the leafs were cut to open the inner parts. The inner surfaces were scraped off with a sterile cutter. The resultant tissues were serially diluted, spread on 1/2 strength ZoBell $2216 \mathrm{E}$ marine agar medium and incubated at room temperature for 48 hours. Purification and isolation of bacterial colonies were performed by using streak plates on the basis of morphological features [7].

\subsection{Isolation of Marine Biofilm-Forming Bacteria}

Isolation was carried out according to a modified method [8]. Four pre-sterilized wooden slides had been deployed in 4 different directions around each seagrass colonies for a week. The biofilm developed in these wooden slides were then aseptically rinsed with sterile seawater, scrapped off with a sterile knife and diluted. One hundred $\mu \mathrm{l}$ of each dilution was spreaded onto $1 / 2$ strength ZoBell 2216E and incubated at room temperature for 48 hours. Colonies with distinguished feature were selected and purified.

\subsection{Extraction of Active Bacterial Symbionts}

Each of active bacterial symbiont was grown in a $500 \mathrm{ml}$ flask containing ZoBell2216E broth medium and incubated for $4 \mathrm{~d}$ in a shaker. The cultures were then centrifuged at a speed of 12,000 rpm for 5 minutes and the supernatants were collected. Supernatants were then extracted based on liquid-liquid extraction on separatory funnel (4 supernatan: 1 n-hexane). The extracts were concentrated by using a rotary evaporator and kept in freezer until antifouling activity was performed.

\subsection{Antifouling Activity Test}

Antifouling test of bacterial symbionts of seagrasses against marine biofilm-forming bacteria was performed by using an overlay method. Culture of each marine biofilm-forming bacterium in the logarithmic phase (ca. $10^{9}$ cells $\cdot \mathrm{ml}^{-1}$ ) was

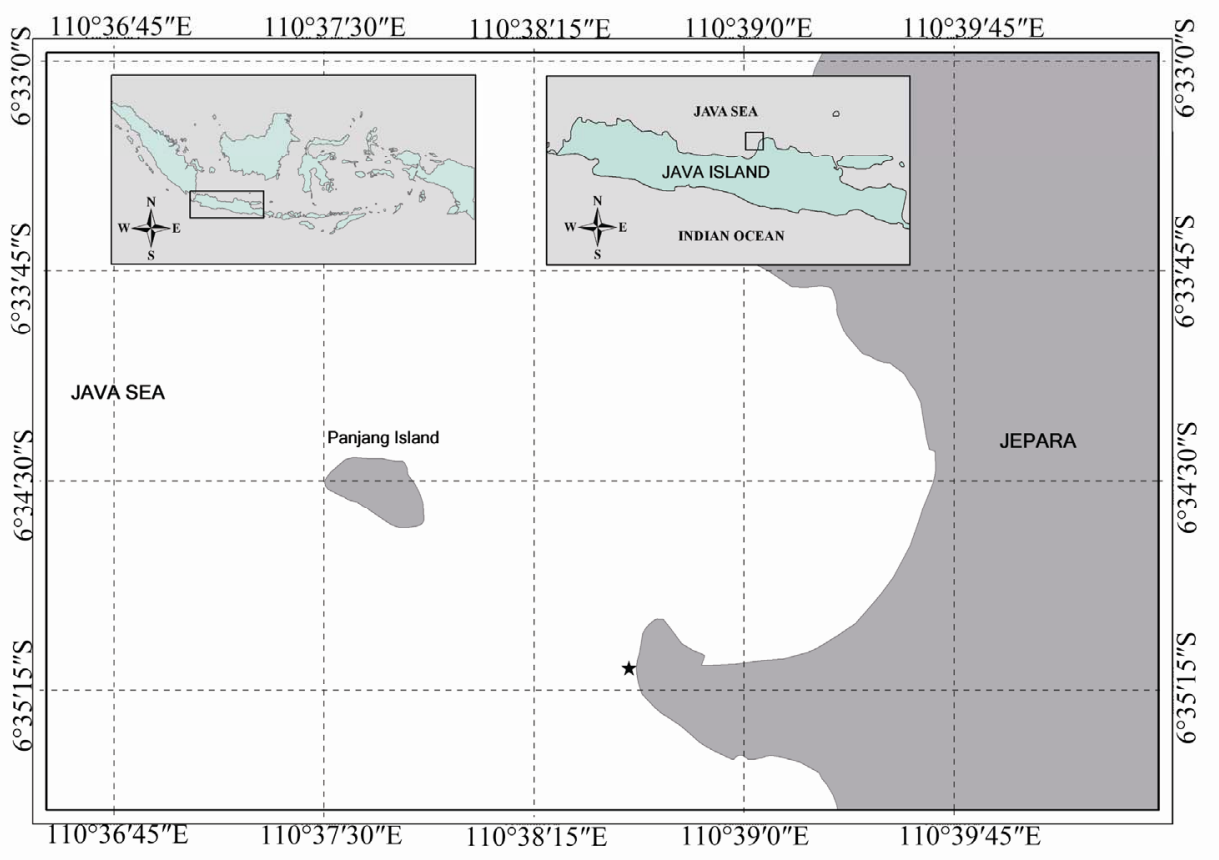

Figure 1. Sampling site at Teluk Awur, Jepara, Central Java, Indonesia. 
mixed with ZoBell 2216E soft agar medium (1\% v/v), which were then poured on to the respective agar surface previously inoculated with bacterial symbionts and incubated for $4 \mathrm{~d}$. The plates were then incubated at room temperature for 48 hours. As for bacterial extracts, an agar diffusion method [9] was performed. Tweenty microlitters of each extract was poured onto a paper disk (8 mm, Advantec, Toyo Roshi, Tokyo, Japan) previously put on agar surfaces containing each biofilm-forming bacterium. Antibacterial activity was defined by the formation of inhibition zones around the bacterial colonies.

\subsection{PCR Amplification and Sequencing of $16 S$ rRNA Gene Fragments}

PCR amplification of partial 16S rRNA gene of active strains and marine biofilm-forming bacteria, purification of PCR products and subsequent sequencing analysis were performed [9]. The determined DNA sequences of strains were then compared for homology to the BLAST database. A phylogenetic tree was constructed using maximum-likelihood analysis and Phylogenetic analysis was performed with the PAUP software package [10].

\subsection{Nucleotide Sequence Accession Number}

The 16S rRNA gene sequences of the active bacterial symbionts of seagrasses have been deposited into the DNA Database Bank of Japan with the following accession numbers: AB665240-43.

\section{Results and Discussion}

This work represents an effort towards finding alternative solution to the problem of marine biofouling, a serious problem faced by worldwide maritimes industries [11] and leads to huge economic losses [12].

Four bacterial symbionts of seagrasses were found to inhibit the growth of marine biofilm-forming bacteria ranging from 1 - 6 bacteria (Table 1). Out of 4 active isolates, 3 isolates were obtained from seagrass E. coroides and 1 isolate was from seagrass T. hemprichii. Interestingly, the crude extracts of these active bacterial symbionts showed more pronounced growth inhibition with a range of 6 - 14 bacteria (Table 1).

The potential of seagrass species of Cymodocea serrulata and Syringodium isoetifolium collected from the coastal area of Tuticorin has confirmed the biological activity of these seagrasses against biofilm-forming bacteria [6]. It is very reasonable that biofilm-forming bacteria have been the primary target for controlling biofouling due to their important cues for larval settlement and development of biofouling organisms [13]. However, considering the issue of bottleneck of most marine natural products and the need of sustainable use of coastal ecosystems as well as the concerns regarding the colle- ction marine resources for discovery and development of marine natural products [14], has turned marine microorganisms such as marine microbial symbionts as a potent source of marine antifoulings. Unfortunately, less data are available of the antifouling compounds produced by marine bacteria [15-17].

The present work show the biological activity against marine biofilm-forming bacteria from the surrounding collonies of these seagrass species that were exposed into the same ecological conditions. Both endophite and epiphytes were found to inhibit the growth of marine biofilm-forming bacteria. Interestingly, all extracts from the active isolates showed broad spectrum of antifouling activity against marine biofilm-forming bacteria. This finding is very important in regards to the fact that bacteria are the primary colonizers and play significant roles in the mediatory effects on the settlement and development of biofouling $[13,18]$. The higher number of biofilm-forming bacteria inhibited by the extracts of active symbionts may indicate the chemical diversity of secondary metabolites produced by the bacterial symbionts. In addition, the fact that non-polar bacterial extracts were found to be active, is a higly desirable in term of possible application of in the marine environment so that it won't be washed out easily. Furthermore, the work also confirmed the bacterial symbionts of seagrass species T. hemprichii and E. acoroides provide sustainable use of seagrass ecosystems in term of developing a largescale cultures of bacterial symbionts for possible commercial development.

The active bacterial isolates were closely related to the members of genus Bacillus and Virgibacillus with highest homology of 98\% - 99\% (Table 2). Molecular phylogenetic (Figure 2) shows that all active isolates belonged to the family Bacillaceae. It is revealed that isolates EA2.1 and EA. 6 belong to Bacillus aquamaris and Bacillus sp., respectively. On the other hand, isolates ESJ.5 and TT.9 belong to Virgibacillus olivae and Virgibacillus marismortui.

A report on the biological activity of bacterial symbionts of sponge Pseudoceratina purpurea shows that they actively inhibited the growth of fouling bacteria isolated from natural marine biofilm. The 3 active isolates belonged to genus Bacillus and 1 isolate belonged to Virgibacillus and were also found to show a broad spectrum biological activity against marine biofilm-forming bacteria [19].

In another study, various marine bacteria associated with a range of marine surfaces were screened and showed potential application as natural antifoulants and found that the isolates were related to Bacillus mojavensis and Bacillus firmus [18]. A screening on bacterial symbionts of softcoral Sinularia sp.and it was found 
Table 1. Growth inhibition of biofilm-forming bacteria by bacterial symbionts and their crude extracts.

\begin{tabular}{ccccc}
\hline No & Isolate & Type of symbiont & $\begin{array}{c}\text { No of biofim bacteria inhibited by } \\
\text { bacterial symbiont }\end{array}$ & $\begin{array}{c}\text { No of biofilm bacteria inhibited by } \\
\text { extract of symbiont }\end{array}$ \\
\hline 1 & EA2.1 & Ephyphite & 3 & 8 \\
2 & EA.6 & Ephyphite & 1 & 6 \\
3 & ESJ.5 & Endophite & 2 & 6 \\
4 & TT.9 & Ephyphite & & 9 \\
\hline
\end{tabular}

Table 2. Molecular identification of active bacterial symbionts of seagrasses.

\begin{tabular}{ccccc}
\hline No & Isolate & Source & Closest relative & Similarity (\%) \\
\hline 1 & EA2.1 & E. acoroides & Bacillus aquamaris & 99 \\
2 & EA.6 & E. acoroides & Bacillus sp. & HQ743752 \\
3 & ESJ.5 & E. acoroides & Virgibacillus olivae & 99 \\
4 & TT.9 & T. hemprichii & Virgibacillus marismortui & 99 \\
\hline
\end{tabular}

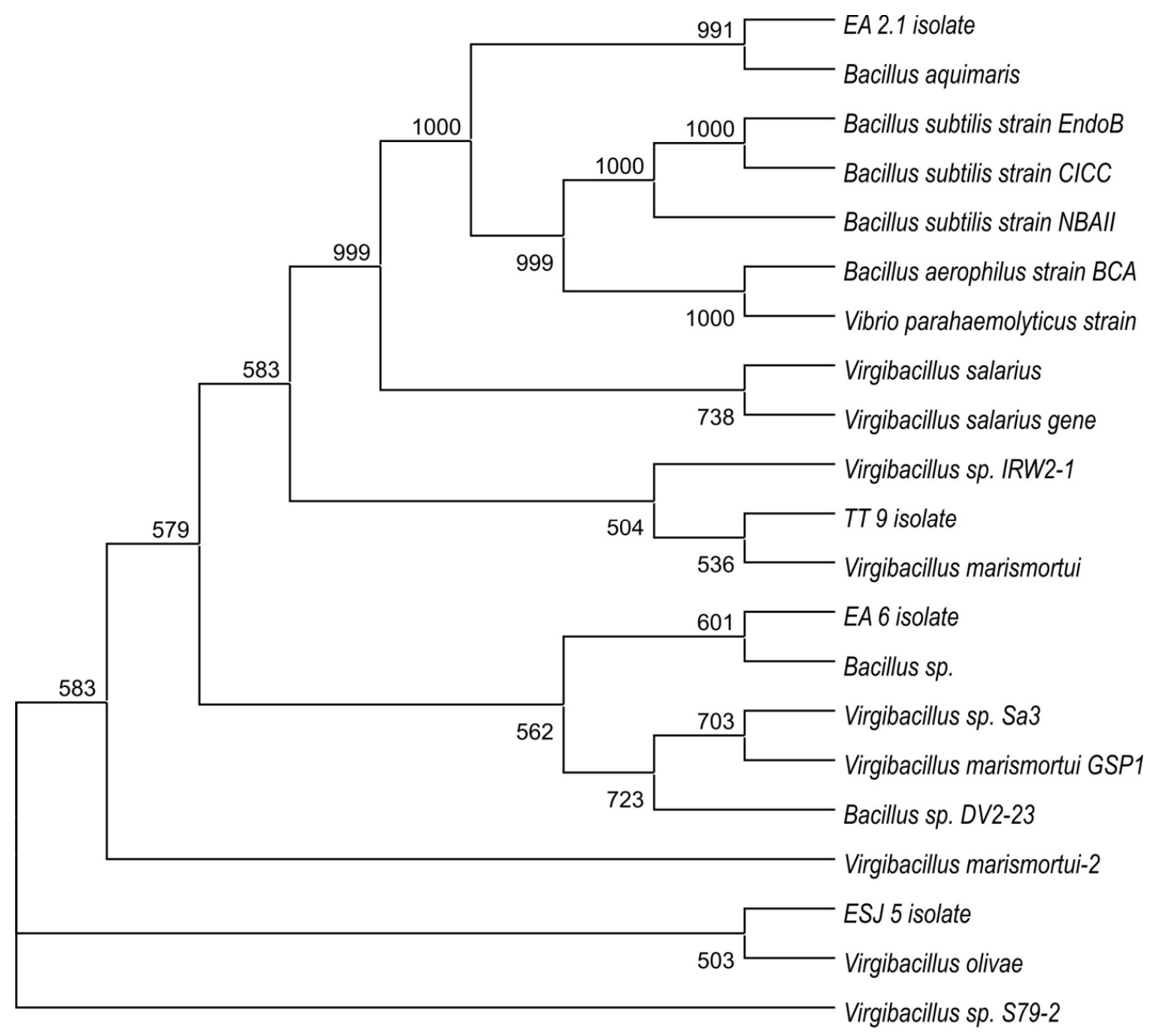

Figure 2. Phylogenetic affiliation of bacterial symbionts of seagrasses. 
that the member of genus Virgibacillus inhibited the growth of MDR strain Staphylococcus aureus [19].

In conclusion, the present study represents the potential of bacterial symbiont of seagrass species T. hemprichii and E.acoroides as the alternative source of environmentally friendly marine antifoulant. The so far uncharacterized secondary metabolites from these active bacterial symbionts deserve futher work on the bioassayguided isolation and purification of the active antifouling compounds.

\section{Acknowledgements}

We appreciated the help of the technicians of Marine Station of Diponegoro University during the sampling. This work was partly supported by a research grant from Biosecurity Engagement Program (BEP), grant \#IDB121003-JA-08 through the US Civilian Research \& Development Foundation (CRDF). Dr. Radjasa was awarded grants from International Foundation for Science (IFS), Sweden (Contract. No. F/3965-2) and Directorate General of Higher Education, Ministry of National Education within "Hibah Strategis Nasional" scheme.

\section{REFERENCES}

[1] R. C. Pereira, A. G. V. Carvalho, B. A. P. Gama and R. Coutinho, "Field Experimental Evaluation of Secondary Metabolites from Marine Invertebrates as Antifoulants," Brazilian Journal of Biology, Vol. 62, No. 2, 2002, pp. 311-320. doi:10.1590/S1519-69842002000200015

[2] M. E. Callow and J. A. Callow, "Marine Biofouling: A Sticky Problem,” Biologist, Vol. 49, 2002, pp. 1-4.

[3] H. Dang and C. R. Lovell, "Bacterial Colonization and Early Succession on Surfaces in Marine Waters as Determined by Amplified rRNA Gene Restriction Analysis and Sequence Analysis of 16S rRNA Genes," Applied and Environmental Microbiology, Vol. 66, No. 2, 2000, pp. 467-475.

[4] I. K. Konstantinou and T. A. Albanis, "Worldwide Occurrence and Effects of Antifouling Paint Booster Biocides in the Aquatic Environment: A Review," Environment International, Vol. 30, No. 2, 2004, pp. 235-248. doi:10.1016/S0160-4120(03)00176-4

[5] P. R. Jensen, K. M. Jenkins, D. Porter and W. Fenical, "Evidence that a New Antibiotic Flavone Glycoside Chemically Defends the Sea Grass Thalassia testudinum against Zoosporic Fungi," Applied and Environmental Microbiology, Vol. 64, No. 4, 1998, pp. 1490-1496.

[6] P. Mayavu, S. Sugesh and V. J. Ravindran, “Antibacterial Activity of Seagrass Species against Biofilm Forming Bacteria,” Research Journal of Microbiology, Vol. 4, No. 8, 2009, pp. 314-319.

[7] M. T. Madigan, J. M. Martinko, J. Parker and T. D. Brock, "Biology of Microorganisms," Prentice-Hall, Inc., New
Jersey, USA, 2000.

[8] O. K. Radjasa, T. Martens, H.-P. Grossart, T. Brinkoff, A. Sabdono and M. Simon, "Antagonistic Activity of a Marine Bacterium Pseudoalteromonas luteoviolacea TAB4.2 Associated with Coral Acropora sp," Journal of Biological Sciences, Vol. 7, No. 2, 2007, pp. 239-246.

[9] O. K. Radjasa and A. Sabdono, "Ecological Role of a Softcoral-Associated Bacterium Arthrobacter sp. on Marine Biofilm-Forming Bacteria,” Microbiology Indonesia, Vol. 2, No. 2, 2008, pp. 7-12.

[10] S. Abarzua, S. Jakubowski, S. Eckert and P. Fuchs, "Biotechnological Investigation for the Prevention of Marine Biofouling II. Blue-Green Algae as a Potential Producers of Biogenic Agents for the Growth Inhibition of Microofouling Organisms,” Botanica Marina, Vol. 42, 1999, pp. 459-465.

[11] D. M. Yebra, S. Kiil and K. Dam-Johansen, “Antifouling Technology-Past, Present and Future Steps towards Efficient and Environmentally Friendly Antifouling Coatings,” Progress in Organic Coatings, Vol. 50, No. 2, 2004, pp. 75-104. doi:10.1016/j.porgcoat.2003.06.001

[12] P.-Y. Qian, S. C. K. lau, H.-U. Dahms, S. Dobrestsov and T. Harder, "Marine Biofilms as Mediators of Colonization by Marine Macrooganisms: Implications for Antifouling and Aquaculture,” Marine Biotechnology, Vol. 9, No. 4, 2007, pp. 399-410.

[13] Sukarmi and O. K. Radjasa, "Bioethical Consideration in the Search for Bioactive Compounds from Reef's Invertebrates," Journal of Applied Sciences, Vol. 7, No. 8, 2007, pp. 1235-1238. doi:10.3923/jas.2007.1235.1238

[14] N. Fusetani, “Biofouling and Antifouling," Natural Product Reports, Vol. 21, 2004, pp. 94-104.

[15] S. Dobretsov, H.-U Dahms and P.-Y. Qian, "Inhibition of Biofouling by Marine Microorganisms and Their Metabolites,” Biofouling, Vol. 22, No. 1, 2006, pp. 43-54.

[16] V. J. Paul, M. P. Puglisi and R. Ritson-Wlliams, "Marine Chemical Ecology,” Natural Product Reports, Vol. 23, 2006, pp. 153-180.

[17] M. Kanagasabhapathy, H. Sasaki, K. Nakajima, K. Nagata and S. Nagata, "Inhibitory Activities of Surface Associated Bacteria Isolated from the Marine Sponge Pseudoceratina purpurea," Environmental Microbiology, Vol. 20, 2005, pp. 178-185.

[18] B. O. Ortega-Morales, M. J. Chan-Bacab, E. MirandaTello, M.-L. Fardeau, J. C. Carrero and T. Stein, "Antifouling Activity of Sessile Bacilli Derived from Marine Surfaces,” Journal of Industrial Microbiology and Biotechnology, Vol. 35, 2008, pp. 9-15. doi:10.1007/s10295-007-0260-2

[19] S. Sulistiyani, S. A. Nugraheni., M. H. Khoeri, A. Sabdono, and O. K. Radjasa, "Antibacterial Activity of Bacterial Symbionts Softcoral Sinularia sp. against Pathogenic Resistant Bacteria,” Journal of Coastal Development, Vol. 13, No. 2, 2010, pp. 113-118. 